\title{
The Being and Becoming of African Diaspora Art
}

\author{
JACQUELINE FRANCIS
}

By and large, "African diaspora art" is a generic label, presently applied with the purpose of broadly situating modern and contemporary artwork by people of African descent in discussions of African art, most often in connection with "traditional" West African ritual sculpture, installation, and performance. I focus on the work that this term has done or has been summoned to do in the US since the late twentieth century. This essay considers several artistic projects and critical and institutional missions linked to African diaspora art and culture: (I) a I 960 s essay by art historian Robert Farris Thompson that organizes nineteenth-century material culture under this heading, (2) the black body as icon of the African diaspora in in the work of US artist David Hammons from the I970s, and (3) the founding of the Museum of the African Diaspora (MoAD) in San Francisco in 2002. We are in the process of institutionalizing African diaspora art, situating it as a cultural consciousness that supersedes other identifications and narratives of association. We value and celebrate this epistemological construct, and, in doing so, reveal that it is also a social formation driven by doubts about racial and national belonging and the desire for a transformative signification and new, organizing logics of being.

Cultural identity ... is a matter of "becoming" as well as of "being."

Stuart Hall ${ }^{\mathrm{I}}$

By and large, "African diaspora art" is a generic label, often summoned to broadly situate modern and contemporary artwork by people of African descent and to connect it to "traditional" West African ritual sculpture, installation, and performance. ${ }^{2}$ It is a valued and celebrated epistemological construct; it is also a social formation driven by doubts about racial and national belonging and the desire for a transformative signification and organizing logics of difference. We are in the process of institutionalizing

California College of the Arts (San Francisco, CA), Graduate Program in Visual and Critical Studies. Email: jfrancis@cca.edu.

'Stuart Hall, "Cultural Identity and Diaspora" (1990), reprinted in Nicholas Mirzoeff, ed., Diaspora and Visual Culture (New York: Routledge, 2000), 2 I-33, 23.

${ }^{2}$ A version of this essay was delivered as a keynote address at the Art across Frontiers: Crosscultural Encounters in America symposium at the University of Nottingham, 28 April 20 I I. Arguments made here are also drawn from a commissioned essay, "African Diaspora Art: Some History and Working Definitions," which is in the privately published exhibition catalogue, Past Forward: African Spirituality in Contemporary Black Art (San Francisco, 2010). 
African diaspora art, situating it as a cultural consciousness that is meant to supersede other powerful identifications and narratives of political association.

Rather than strain to define what African diaspora art is, I will examine some work that this term has done or has been summoned to do in the US in the late twentieth century.

I consider artistic, institutional, and scholarly interventions that laid out and advanced the terms of African diaspora art as a category: (I) a I960s-era essay by art historian Robert Farris Thompson that organizes nineteenthcentury material culture under this heading (without naming it as such); (2) David Hammons's moves to cultivate an audience for African diaspora art, from the I970s onwards; and (3) the founding of the Museum of the African Diaspora (MoAD) in San Francisco in 2002. Early on, Thompson and Hammons transformed the terrain, formalizing the content and practice of what they argued was a sociocultural and racial tradition, alternately termed African Atlantic, black Atlantic, and African diasporic. In many ways, their efforts drove an African diaspora visual turn that culminated in the call for institutions such as MoAD. To say this does not make them the principal architects, or the singular laborers, who, brick by brick, built cultural organizations dedicated to African culture. ${ }^{3}$ But I do want to situate Thompson's and Hammons's projects as generative work that also brought significant pressure to bear on overlapping categories that signified black culture and ontological blackness, including African art and African American art. ${ }^{4}$ For much of the twentieth century, African art and African American art designated objects to be studied, collected, and displayed, and these headings gained traction in many sectors of the cultural economy, from museums and auction houses to university syllabi and dedicated publications. ${ }^{5}$ Yet African

${ }^{3}$ In a 2010 paper written for a College Art Association panel I cochaired (with Krista Thompson), Judith Bettelheim places African diaspora art history's origins in the I940s: anthropologists' investigations of the US South by Melville Herskovits and others initiated in that decade and the Museum of Modern Art's 1944 exhibition Modern Cuban Painters of 1944. Judith Bettelheim, "An Historiography of African Diaspora Art History: A Work in Progress," paper read at the annual meeting of the College Art Association, Chicago, I 2 March 2010.

${ }^{4}$ To state what is widely known: in the popular and academic realm, "African art" mostly designates study of sub-Saharan expressive culture, which is widely seen as the continent's "black zone." The popular understanding of African art is that it is and has been made by black people, and that it informs the art of the African diaspora, including African American art, i.e. art made by black people in the United States. Northern African art, produced in Algeria, Egypt, Libya, Mauritania, Morocco, South Sudan, Sudan, Tunisia, and Western Sahara, is not considered African art; peoples in these nations and territories are not considered black. Instead, they and their cultural production are assigned to "the Arab and/or Islamic worlds."

${ }^{5}$ Krista Thompson engages many of these developments in her interdisciplinary examination of African diaspora art's historiography "A Sidelong Glance: The Practice of African Diaspora Art History in the United States," Art Journal, 70, 3 (Fall 20 I I), 6-3 I. 
diaspora art, and especially the conceptualization of what it is and what it does, has involved a set of operations that are different from those put in motion by African art and African American art, both profitably rooted in chronology, geography, and history. In the present, the distinctiveness of "African diaspora art" lies not only in what it embraces and lays claim to, but also in its "being and becoming" a field, a practice, and a narrative.

Yes, I am political if it is a political statement to say that African-Atlantic culture is fully self-possessed, an alternative classical tradition ... But I'm saying more than that. I'm saying that it is just as good.

Robert Farris Thompson ${ }^{6}$

More than three decades before Thompson made this claim in an interview, he had laid groundwork for it in "The African Influence on the Art of the United States." 7 Though the phrase "African diaspora" is never invoked in this 1969 essay, the concept resonates throughout it, for Thompson situated his research alongside earlier scholarship that mentioned transatlantic aesthetic linkages. ${ }^{8}$ Nonetheless, Thompson writes with greater conviction than his predecessors, insisting that material culture made by black American artists of the eighteenth, nineteenth and twentieth centuries bore African influences:

amazing stoneware vessels, shaped in the form of anguished human faces made by Afro-Americans in South Carolina ... multiple wood carving modes in tidewater Georgia, basketry modes of astonishing purity near Charleston, the deliberate decoration of graves in the African manner with surface deposits of broken earthenware and possessions in many parts of the Deep South, and isolated instances of Afro-American wood carving in Livingston County, Missouri, and Onondaga County, New York.9

${ }^{6}$ Donald J. Cosentino, "Interview with Robert Farris Thompson," African Arts, 25, 4 (Oct. 1992), 52-63, 59, emphasis in the original. Robert Farris Thompson is no relation to Krista Thompson.

${ }^{7}$ Thompson's essay was a revised version of his lecture at a 1968 Yale University symposium, Black Studies in the University.

${ }^{8}$ On the first page of his essay, Thompson cites James A. Porter's exhibition catalogue contribution "One Hundred and Fifty Years of Afro-American Art," where he writes on page 6: "The crafts of weaving, wood carving and embroidery also allows us to discern the retention of African features; and Cedric Dover in his American Negro Art illustrates an interesting type of 'plantation pottery' produced by slave craftsmen of North and South Carolina that bears unmistakable signs of African recollection in peculiarities of surface design." Yet later in this seven-page essay, Porter - an African American painter and art historian-asserts that African art, historically disparaged for centuries, had not been a resource for twentiethcentury black art. According to Porter, "It might be that the fructifying influence of African art on modern Afro-American art is not yet spent." James A. Porter, "One Hundred and Fifty Years of Afro-American Art," in Frederick S. Wight and James A. Porter, The Negro in American Art (Los Angeles: UCLA Art Galleries, I 966), 8-9.

9 Robert Farris Thompson, "African Influence on the Art of the United States," in Armstead L. Robinson et al., eds., Black Studies in the University (New Haven: Yale University Press, I969), I22-70, I 27. 
Writing specifically about the sculpture, Thompson identified seven traits that he believed suggested African influence in these plastic arts: monochromy or bichromy; smooth, luminous surfaces; symmetrical organization of forms; mask-like faces; beaded, shell, or metal eyes; synoptic vision; and the symbolic representation of reptilian, amphibian, and human figures. Thompson praised these vernacular works and considered them "parallel visual continuities" to acknowledged "African-influenced verbal arts (Aunt Nancy tales), healing (conjuring), cuisine (hog maws and collard greens), singing (field hollers and work songs), and dance forms." ${ }^{\circ}$

The traditional art of the Afro-American in the United States represents a fusion and simplification of some of the themes of sculpture of West Africa ... In time the contours of an entire tradition will emerge, sufficient to discredit to the apriorists, who believe that the traditional Afro-American art of the United States is "devoid of tribal and religious associations" and is merely the work of isolated folk craftsmen, hence not on the level of legitimate art historical concern. The old assumptions, which elevate ignorance to definition, will disappear before the truth. ${ }^{11}$

In these passionately written lines, Thompson insisted that there was a US tradition of African-influenced art worthy of historical study.

Thompson was well suited to undertake this revisionist task. Three years prior to the publication of this essay, Thompson earned a $\mathrm{PhD}$ in African art history; he was only the second person in the United States to do so. ${ }^{12}$ Before he traveled to Nigeria in the 1960 s to study the aesthetics of Yoruba dance wands, Thompson had taken sojourns to New York City, Mexico City, Havana, and Port-au-Prince in the I950s, soaking in Puerto Rican jazz and dance hall music, Caribbean mambo, and vodou rituals, all of which he reasoned were what he later called "Africanizing currents." ${ }^{\text {13 }}$ In a word, Thompson first experienced "Africa" through its diaspora and set out to theorize it by picking up languages (from Spanish and Yoruba to Arabic and French) and by fashioning an interdisciplinary research method grounded in archaeology, comparative literature, connoisseurship, formalism, and history. Notably, he inserted himself - a white American whose childhood in El Paso, Texas generated his love of its "alternative culture with people who were brown" - into

\footnotetext{
${ }^{10}$ Ibid., 127.

${ }^{11}$ Ibid., I 64-65.

${ }^{12}$ Roy Sieber's PhD dissertation, "African Tribal Sculpture" (1957, University of Iowa) preceded Thompson's "Yoruba Dance Sculpture: Its Contexts and Critics" (1965, Yale University). At Yale, Thompson studied under the pre-Columbianist George Kubler, whom he considered a godsend: "In spring 1955, I found a guy with a mind so open that there was no danger anymore. By accident I wandered into George Kubler's course on Mesoamerican antiquity. I came alive. Here was a course where you actually memorized objects from beyond the West, that were made by men and women from another tradition. Although Mexico is technically a Western nation, we all know that it has Native American impulses everywhere." Cosentino, "Interview with Robert Farris Thompson," 55.

${ }^{13}$ Cosentino, "Interview with Robert Farris Thompson," 55.
} 
the evolution of an African diaspora cultural field, albeit one whose contours were not fully formed. ${ }^{14}$

Thompson's project to elevate the profile of African diaspora art in the US and to situate it as the equal of canonical Western art - past, present, and future - should be considered alongside other transformative emanations of the 1960 s. In this decade of black power, the free speech movement, and other countercultural protests and uprisings, Thompson's writing - formalist and connoisseurial in tone-was also scholarly activism. It was an insistent rejection of the traditional cultural hierarchy in the US and it offered itself as a new model that could replace the old. Towards this end, the work discussed in Thompson's 1969 essay, like the sculpture, fabric, and graphic art exhibited in a 1968 show he curated, African and Afro-American Art: The Trans-Atlantic Tradition, was presented in utopian terms: Thompson wrote and spoke of them as superior artistry and culturally authentic craft, produced by creative agents driven by high-minded morals and ethical purpose. Reviewing the latter, critic John Gruen saw the "proof-positive that the Negro has a vast and telling art historical tradition." Yet while Gruen tells his readers that Thompson's exhibition will sweep away notions of "static" African art, he explains the work as an atavistic outcome: "There are immense ties between the visual arts of West Africa with the arts of the blacks in North America, the Caribbean, and South America - and, amazingly, these ties often appear unconsciously." is Gruen effectively dashed to bits Thompson's intellectual labor - the formalist consideration, the connoisseurial attention - and took away only Thompson's retentionist narrative.

I like doing stuff better on the street, because the art becomes just one of the objects that's in the path of your everyday existence. It's what you move through, and it doesn't have any seniority over anything else.

David Hammons ${ }^{16}$

Around the time of Thompson's 1969 essay, artist David Hammons was searching for ways to figure the African diaspora in his visual practice, and, in doing so, to make modern black identities equally cultural, material, and political. In the I 960 and 1970 s, Hammons made prints in which he stamped his body on treated supports to become, in the well-chosen words of art historian Mary Schmidt Campbell, "both the creator of the object and the

${ }^{14}$ [James Stevenson], “Talk of the Town - Keeping Things Cool," New Yorker, 44, 9 (Nov. I 968$), 54$.

15 "Art in New York - The Messrs. Clean," New York, I, 26 (30 Sept. 1 968 ), i 3.

${ }^{16}$ Hammons, quoted in interview with Kellie Jones, Real Life, I6 (Autumn 1986), 4, reprinted in Jones, "David Hammons," in Russell Ferguson et al., eds., Discourses: Conversations in Postmodern Art and Culture (Cambridge, MA: MIT Press, 1990), 209-I 9, 2 I I. 
object of meaning." ${ }^{17}$ Looking at Hammons's better-known body prints, such as Spade (Power for the Spade) (1969) and Injustice Case (1970) - it seems that there could be no better way of communicating distinction - individual, cultural, and artistic - and elemental difference (for no two bodies are exactly alike). However, as I have argued elsewhere, the breadth of subject in some of Hammons's more obscure body prints, among them the no-longer-extant Rabbi (mid-i960s), challenges readings that these works are exclusively a "discourse" on "aesthetic blackness." ${ }^{8}$ Hammons, in discovering the expressive potential of his body and its mobility as subject, sought other means to present his identification with a black experience grounded in transnational symbols and affiliations.

Hammons tethered Africa to the Americas, textually and bodily, in Zaire, a street performance, enacted in Los Angeles and New York City in the midI 970 . In documentary photos, the Mid-western-born Hammons is "deAnglo-cized”: he holds a beaded walking stick, wears a knit Rastafarian tam, and sports dreadlocks. In some frames, he poses before a wall on which the nation-state's name is spray-painted; in another, he prostrates himself beneath this tag "Zaire," offering an open-ended gesture of respect or of mourning. Here, he points to the lower case "i" in Zaire, which seems to link his American body to this African country. With these public moves, none of which comprises "African art" or makes Hammons an "African," 19 the artist, at the very least, drew the attention of passersby to Zaire as place of note. ${ }^{20}$

${ }^{17}$ Mary Schmidt Campbell, Tradition and Conflict: Image of a Turbulent Decade, 1963-1973 (New York: Studio Museum in Harlem, 1985), 61. Quoted in Jones, "David Hammons," 17. Jones writes, "Hammons used his body as the printing plate, smearing it, as well as his clothes and hair, with margarine or other grease. Then, he pressed himself against a board and finally, to set the impression, dusted the board with fine chalk or other pigment. In these pieces Hammons became "both the creator of the object and the object of meaning."'

${ }^{18}$ I discuss the decentering move of Rabbi in "To Be Real: Figuring Blackness in Modern and Contemporary African Diaspora Art," Radical History Review, 103 (Winter 2009), 1 88-202. Art historian Richard J. Powell has written that "Hammons's postmodernism is conditioned to a great extent by what Lowery Sims has described as 'the Black Art debates': arguments that - because of their preoccupation with terminology, art world status (or the lack thereof), and the dialectic between artistic expressivity ('hot') and artistic detachment ('cool') - have triggered in Hammons his own, idiosyncratic, visual discourse on the lengths to which aesthetic blackness can be stretched." Richard J. Powell, "African-American Postmodernism and David Hammons," in David C. Driskell, ed., African American Visual Aesthetics: A Postmodernist View (Washington, DC: Smithsonian Institution Press, 1995), I $21-38$, 135.

${ }^{19}$ Powell, at $134-35$, has characterized Hammons's practice in this way: "Hammons's postmodernism is in part nourished by an African impulse: a conscious and/or unconscious overture to the past-real or imagined-that encourages an art of spirituality and remembrance."

${ }^{20}$ What was it that Hammons intended to highlight in Zaire? The I971 renaming of the country - from Congo to Zaire - and of its cities and towns which bore the imprint of European colonialism and imperialism? Zaire's "authenticity" policy of the early I 970 s in 
Hammons's preferred dialogist traverses the urban street. Throughout his career, he has frequently articulated his antipathy to elite art spaces and the populations that visit them. In a 1986 interview, the artist asserts,

The art audience is the worst audience in the world. It's overly educated, it's conservative, it's out to criticize[,] not to understand, and it never has any fun. Why should I spend my time playing with that audience? That's like going into a lion's den. So I refused to deal with that audience and I'll play with the street audience. That audience is much more human and their opinion is from the heart. They don't have any reason to play games, there's nothing gained and lost. ${ }^{21}$

For Hammons, who has never abandoned the commercial art market or eschewed gallery and museum exhibitions, such rhetoric is a central aspect of his refusé practice. In it, making art is a freer and more honest kind of "play"; reception, which should not be informed by emotion and feeling (and too much education), mirrors the artist's open-spirited creativity and the fun it might generate. Hammons's Bliz-aard Ball Sale (1983) is a realization of Hammons's aspiration. Staged in Manhattan's Greenwich Village neighborhood, it was a performance that parodied high and low marketplaces - that of New York streets on which used books, records, and clothing were sold right from the sidewalk, and that of the city's galleries, auction houses, and museums where the commodity was "fine art." Bliz-aard Ball Sale's handmade objects-white, round, and in a variety of circumferences-perfectly emblematized the subjective registers of taste, and were send-ups that ridiculed the constructed social status of whiteness as a racial category as well.

Beyond site-specificity, Hammons also has courted a specific audience. About the response to bottle trees he made in Harlem, New York in the early I 980 s, Hammons candidly recalled that

some people asked me what I was doing and somebody said, "He ain't got nothing better to do." And I thought, I didn't have anything to do, that was reason I was doing it. So they ask the questions and answer them themselves. If you're or don't have anything to say, they say it all for you ... They call my art what it is ... They're the number one, because they're already at the place that I'm trying to get to. ${ }^{22}$

In this statement, Hammons posits a nonhierarchical relationship with a no-nonsense black public on which, he says, he depends. Everyday people observed the bottle trees and the much-written-about assemblage Higher Goals

which its citizens forswore their Western names in favor of indigenous, local ones? The centralization of state power and the diminution of local authority, including chieftainships? The forced-labor system that obliged citizens to work weekly on agricultural and development projects? The establishment of one-party rule? The "Rumble in the Jungle," the heavyweight championship fight between African American boxers Muhammad Ali and George Foreman?

${ }^{21}$ Quoted in Jones, "David Hammons," 215.

${ }^{22}$ Quoted in Jones, "David Hammons," 214 , 215. 
(1986); whether they "got it" or not, their feedback shaped his creative thinking and influenced his strategic trajectory. Furthermore, "they're already at the place that I'm trying to get to," Hammons asserted. What is that "place"? Where is it? Not Greenwich Village, but rather Harlem, the twentieth-century mecca of black America. Additionally, Hammons's sights are trained upon an Anschauung, a view, and pointedly one that is characteristically independent, autonomous, self-reliant, and without borders that separate the peoples of the African diaspora. In this framework, institutional critique is not only lodged by the artist, but by a black diasporic constituency that, however alienated by the Eurocentrism of Western visual culture, talks back to it and challenges its authority.

A Macarthur ("Genius") Fellowship-winner (199I), one whose work is in high-profile international collections - from the Museum of Modern Art and the Tate Modern - and has commanded six-figure hammer prices for his drawings, Hammons has created a taste for African diaspora art, albeit in the elite, moneyed circuits he decries. ${ }^{23}$

"That's all we really want, isn't it, a good story?"

Clifton Lemon, "The Louisiana Project at MoAD: Magnificently Mounted Masquerades of Metaphor" ${ }^{24}$

When it opened in the fall of 2005, the Museum of the African Diaspora (MoAD) in San Francisco was among the first American cultural centers to bear "diaspora" in its name. ${ }^{25}$ Yet in the early planning stages, the museum's charge was differently conceived. Then mayor Willie Brown had imagined a museum devoted to black American history and culture. As the first African American mayor in San Francisco's history and as a former California state legislative leader with lasting political clout, Brown was well positioned to move this project forward. Furthermore, San Francisco's black American

${ }^{23}$ Like the artists who once lodged it, institutional critique has "been accorded the unquestioning respect often granted artistic phenomena that have achieved a certain historical status," according to Andrea Fraser, "From the Critique of Institutions to an Institution of Critique," Artforum, 44, I (Sept. 2005), 278-83, 278, 279. Moreover, Fraser asked rhetorically, "How can artists who have become art-historical institutions themselves claim to critique the institution of art? ... Today, the argument goes, there is no longer an outside."

${ }^{24}$ Clifton Lemon, "The Louisiana Project at MoAD: Magnificently Mounted Masquerades of Metaphor," SF Station, 7 Sept. 2006, available at http:sfstation.com/the-louisiana-project-atmoad-a2 162, accessed i9 April 2011.

${ }^{25}$ Preceding MoAD was the Black Arts National Diaspora (BAND), founded by Dr. G. Jeanette Hodge in New York in 1982 and moved to her hometown of New Orleans in 1992. BAND operated out Hodge's home until 2002, when it relocated to a 17,000-squarefoot building. Damaged in the floods that followed hurricanes Katrina and Rita, this repository of paintings and sculptures from Africa and the Americas in currently undergoing renovations. 
artists, citing the lack of exhibition opportunities in the city, supported Brown's initiative. ${ }^{26}$ Yet in an era when the city's African American constituency population was falling precipitously, Brown's twenty-person steering committee recommended that this black museum take "a global perspective." ${ }^{27}$

Unquestionably, MoAD was a political initiative and a textbook example of institution building. The structure itself was meant to be read for its "difference" from neighbors. Its construction was part and parcel of a decadeslong urban "redevelopment" project that transformed San Francisco's South of Market Street (SOMA) area, described in the r950s and I960s as a decrepit, seedy, Skid Row. Despite sustained opposition, industrial buildings in SOMA were razed and its streets were reconfigured to accommodate multistory glass corporate towers and a "culture gulch" of museums and art galleries. ${ }^{28}$ In 1993 , the multidisciplinary Yerba Buena Center for the Arts opened, and two years later San Francisco's Museum of Modern Art (SFMOMA) took up residence across the street in a new $\$ 60$ million postmodernist edifice designed by Swiss architect Mario Botta. ${ }^{29}$ MoAD, sited just around the corner from SFMOMA, was built on land owned by the San Francisco Redevelopment Agency. The agency kicked in $\$ 8$ million for the commissioned design of MoAD and the building's construction. $3^{\circ}$ MoAD shares its footprint on the corner of Third and Market streets with the St. Regis Hotel and Condominiums, whose developer added $\$ 8.3$ million to the project. ${ }^{31}$ By the early 2000 s, SOMA was considered "a knuckle of culture," according to St. Regis Hotel developer Dick

${ }^{26}$ Dinah Eng, "A Reunion of Those Scattered: A New Museum in San Francisco Will Focus on African as the Birthplace of a World of Culture, "Los Angeles Times, 26 Nov. 2005, I I.

${ }^{27}$ Federal integration laws in place since the 1950 s had enabled black middle-class moves to the suburbs. So-called "urban renewal" in that decade and the 1960s fractured and decentered the city's historically black neighborhoods. Lastly, waves of gentrification in the 1980 s and 1990 s and government failure to stem deadly violence and remove environmental hazards in the poorest black enclaves have created isolation and alienation in those communities.

${ }^{28}$ Jesse Hamlin, "Finally, the Pieces Are Coming Together: Jewish Museum and Mexican Museum a Step Closer to Reality," San Francisco Chronicle, i April 2006, Eı o. Also see John King, "The St. Regis Is an Engaging Urbane Success," San Francisco Chronicle, i 4 Dec. 2005, $\mathrm{B}_{\mathrm{I}}$; and King, "Work Begins on Oft-Delayed \$46 Million Jewish Museum: Energetic Design in City's Culture Gulch Reuses Power Station," San Francisco Chronicle, 20 July 2006, BI.

${ }^{29}$ The San Francisco Museum of Art was founded in 1935, and changed its name to the San Francisco Museum of Modern Art in 1975. From 1935 to 1994 the museum was housed on a single floor of a Beaux Arts building in the city's Civic Center.

${ }^{30}$ Jessie Hamlin, "Faces of Africa Create a Tapestry of All Humanity; A New Museum Traces Threads of the Diaspora," San Francisco Chronicle, 25 Nov. 2005, EI.

${ }^{31}$ Ibid. Mayor Willie Brown openly bragged to the press: "The only reason this hotel got built was to house this museum! And because I was mayor, I held the power in deciding where and who built it." Catherine Bigelow, "Swells," San Francisco Chronicle, i I Dec. $2005, D_{4}$. 
Friedman, one he was obliged to instill with a "public benefit." In addition, Friedman explained,

Our feeling was, San Francisco was one of the most important convention cities in the country, and this was an opportunity for people from all over the country and all over the world to experience the African diaspora, the tale. The essence of San Francisco is its diversity, its graininess. This is an effort to celebrate it. ${ }^{32}$

For Friedman and others, MoAD delivered "ethnic and cultural diversity" to the newly gentrified arts district that, as local architectural critic John King put it, could "otherwise be dismissed as a bastion of wealth." 33

While local press generally praised MoAD at the time of the debut, the varied directions and tenor of commendation revealed the lack of understanding about the phrase "African diaspora." Covering MoAD's opening in November 2005, the San Francisco Chronicle repeatedly referred to the institution as an "African museum" in several headlines and news stories. ${ }^{34}$ In these features, "origins" was the focus and MoAD's proclaimed interests in diasporic movement, adaptation, and transformation were rarely acknowledged. For certain, "Africa" played prominently in the titles of MoAD's inaugural shows, Linkages and Themes in the African Diaspora: Selections from the Eileen Harris Norton and Peter Norton Contemporary Collections and Dispersed: African Legacy/New World Reality. Nonetheless, the work of Dispersed participants - San Francisco Bay Area sculptor Mildred Howard, Brazilian installation artist Marepe (Marcos Reis Peixoto), and Cuban-born video artist Magdalena Campos-Pons - presented opportunities to consider the heterogeneity of their practices and of the category "African diaspora art." Only one writer, Sharon Mizota of the conservative SF Weekly, did so and she approached this task warily. Her review of Dispersed opened sharply: "If you worried that the Museum of the African Diaspora might be the latest incarnation of political correctness, fear not." 35 Although she found Marepe's and Campos-Pons's creative strategies wanting, Mizota favorably wrapped up her review, "perhaps more important than their individual merits are the ways that these works defy stereotypical motif and attitudes to honor the complexity and richness of the African-American experience." ${ }^{6}$ Clearly,

${ }^{32}$ Carolyn Zinko, "African (Re)genesis in San Francisco: New Art Museum Pursues Funding, Enrolls Members," San Francisco Chronicle, 7 Dec. 2003, E5.

${ }^{33}$ John King, "The St. Regis Is an Engaging Urbane Success: 450-Foot Tower Is Centerpiece of Project at Third and Mission," San Francisco Chronicle, I 4 Dec. 2005, B I.

${ }^{34}$ See Carrie Sturrock, "Thousands Preview African Museum," San Francisco Chronicle, 27 Nov. 2005, BI; Delfin Vigil, "All Things African," San Francisco Chronicle, 22 Jan. 2006, PKI 8.

${ }^{35}$ Sharon Mizota, review of Dispersed: African Legacy/New World Reality, in "Our Critics Weigh in on Local Exhibits," SF Weekly, 22 Feb. 2006, Arts Section, I.

${ }^{36}$ Ibid. Inexplicably, Mizota, who correctly identifies the three artists' nationalities in her piece, herds the Brazilian Marepe and the Cuban American Campos-Pons under the singularizing 
Dispersed was a discovery for Mizota, who had expected none. The shift in her thinking sits next to her incorrect assignation of the Brazilian Marepe and the Cuban Campos-Pons to "the African-American experience." This singular term, like "African museum," simplified the construct of diaspora museum because, for Mizota and others, it needed to "be" in (or of) one place (or another).

Location does matter, no less than the specifics of the stories neatly mapped atop one another. In 2006, MoAD accepted a traveling exhibition: Carrie Mae Weems's The Louisiana Project, organized by the Newcomb Art Gallery of Tulane University in New Orleans. A commentary on the US purchase of Louisiana in 1803 , The Louisiana Project did not address the catastrophic flooding of New Orleans and other Gulf of Mexico cities and towns in 2005. Instead, this installation featuring the artist's interpretive photography, video, and narrative was a portrait of this southern metropole, starring its architecture, customs, and social relations. Kenneth Baker, the San Francisco Chronicle's chief art critic, most admired Weems's photographs, writing that their "swirl of images and references takes on an unexpected power, partly because of the photographs' casual surrealism and formal poise."

Yet Baker, throughout his ambivalent review, suggests that Weems's subject was too distant for Bay Area viewers whom he thought knew little about New Orleans's Mardi Gras rituals. ${ }^{37}$ Weems's black-and-white photographs, Baker concluded, "have a mystery that sustains the curiosity it takes to learn something of the work's background, which only the exhibition catalogue adequately provides." ${ }^{8} 8$ The thing is, Baker didn't seem aware of local black constituencies with New Orleans and Gulf of Mexico roots: thousands, including former San Francisco mayor Willie Brown, had left this southern region and migrated to the Bay Area in the 1940s and 1950 s in search of better jobs and lifestyles. Among these transplants and their descendants, there was no need for The Louisiana Project's exhibition catalogue or programmed introduction to Gulf culture; they regularly visited the region to see family or attend funerals, and to party during Mardi Gras, Jazzfest, and school reunions, and they knew the terrain well. MoAD was banking on their deep interest in the Gulf history and heritage, a layered narrative that overlapped with the larger public's fascination with the 2005 deluge and the black exodus it provoked.

rubric of "African-American experience" in her wrap-up statement. The slip is symptomatic of the critical desire to make diaspora "one thing" or "another."

${ }^{37}$ Even "with the promptings of wall text, visitors unfamiliar with New Orleans' local traditions and history will have a hard time making sense of 'The Louisiana Project' or imagining the impact it might have on clued-in viewers." Kenneth Baker, "Review: Two Centuries Ago, the US Doubled in Size. At What Cost? One Artist Wonders - in Black and White," San Francisco Chronicle, 29 July 2006, EI. ${ }^{38}$ Ibid. 
"Louisiana" signaled, for Baker, an opportunity to realistically document the drama of a city ruined by wind, water, and human failure to plan for an excess of both. As a conceptual project that engages another history, The Louisiana Project is a let-down for Baker and a triumph for Clifton Lemon, another Bay Area observer. "Weems gets my attention because she has a story to tell. That's all we really want, isn't it, a story?" asks Lemon. ${ }^{39}$ Like links in a chain, the narratives constructed by Thompson, the connections to audience made by Hammons, and the curated exhibitions at MoAD, are stories - differently grounded, researched, and set into motion - of the African diaspora.

In the ensuing years, MoAD has continued to mount exhibitions that display contemporary and historical art, photojournalism, ritual art, and material culture from both Africa and its diaspora. There are equal numbers of exhibitions that somehow characterize both "places" (nearly always positioning the former as the anchor that defines the latter) in representational, abstract, and conceptual visual languages, put into service by black and non-black artists alike. ${ }^{\circ}$ Still, increasingly, the meaning of diaspora at MoAD is communicated through its public programming: there are book talks by authors whose publications include "diaspora" in their titles or examine its histories (or both) and performances by storytellers, singers, and dancers that situate themselves and their artistic expression as diasporic. At MoAD and in and within similarly dedicated structures and infrastructures, African diaspora art is the illuminated enmeshment of marked bodies and the cultural work they produce - indexically, self-reflexively, and, seemingly, naturally.

\footnotetext{
${ }^{39}$ Lemon, "The Louisiana Project at MoAD."

${ }^{40}$ The group exhibitions Decoding Identity: I Do It for My People (2009) and Choose Paint! Choose Abstraction! Celebrating Bay Area Abstract Artists (2012) at MoAD presented work by an interracial slate of artists. MoAD's mission statement proclaims openness: “The Museum of the African Diaspora (MoAD) showcases the history, art and the cultural richness that resulted from the dispersal of Africans through the world. By realizing our mission MoAD connects all people through our shared African heritage."
} 